\title{
Giovanni Badino (1953-2017)
}

\author{
Arrigo Cigna ${ }^{1}$ and Paolo Forti ${ }^{*}$ \\ ${ }^{1}$ International Union of Speleology \\ ${ }^{2}$ Italian Institute of Speleology
}

Giovanni Badino became interested in caves when he was very young and still in high school (lyceum) in Savona (Liguria, Italy). His passion for the underground world increased tremendously when he moved to Turin (Piemonte) to study physics at the university there. Cave exploration and techniques were his first interests, and they remained fundamental throughout the rest of his life. His first paper on a cave was printed in 1971; this was followed by another on new materials for exploration in 1972, year when he became interested in cave meteorology.

During his college years, he found the study of the underground environment from the point of view of a physicist to be fascinating, and from that time on, "cave physics" became his preferred field of research.

Immediately after finishing his university studies, Giovanni became Researcher in Physics, and later Associate Professor at the University of Turin (Italy), where he taught for the rest of his life. By the end of the "70s, he had developed an excellent career in particle physics, and he worked as part of some of the leading international teams on neutrino physics in top-level institutions for about 20 years, as testified to by some 200 scientific papers.

But, at the same time, he was still a devoted explorer and avidly pursued this activity in the most interesting karst areas of Italy (e.g. Antro del Corchia in Tuscany, and Piaggia Bella in the Marguareis Piedmont). These caves served as training sites for his later exploration of an incredible number of caves all over the world in the following 40 years. But during his explorations, he never forgot he was a physicist, and he looked at all aspects of the environment from such a point of view.

His experience in cave exploration worldwide, together with his uncommon ability to transform complex things into easily understandable ones, allowed Badino to become one of the best writers of general books on caves, and he authored some 20 general books, several of which became true bestsellers.

Another area requiring a scientist to be a good explorer is the glaciers, and Badino also became involved in the quantitative evaluation of the phenomenon and processes in glacier caves. At the same time, his initial interest in cave meteorology led him to publish the first general book on the physics of the underground climate in 1995, a book that deals with all aspects of the cave environment.

A few years later, at the beginning of the new millennium, he joined the XVI Italian Expedition to Antarctica and studied the development of karst caves in ice. Since the mean annual temperature there is $-18^{\circ} \mathrm{C}$, it was difficult to accept the explanation of the dissolution of ice in their formation, and even the existence of caves up to $15 \mathrm{~m}$ in length. An accurate investigation, however, revealed a temperature difference between the soil and the ceiling of the caves and, consequently, the role of the circulation of air and the sublimation of ice in the development of speleogenesis well below zero degrees.

Since 2005, he was one of the leaders in the exploration of the Naica caves (Mexico), which host giant gypsum crystals; for that exploration he specifically designed a unique suit with an ice cooling system to enable a whole hour of working time [in the suffocating heat]. During a preliminary test, he had nearly collapsed, but he immediately set out to find the best solution to resolve the problem. A few months later, he had also developed the most accurate temperature data logger ever installed inside a cave (error less than $0.003^{\circ} \mathrm{C}$ ) to evaluate the temperature variations inside the Cueva de los Cristales (Naica, Mexico).

More recently, he directed his investigations to the "breath" of caves. An underground cave system behaves as a Helmholtz resonator, although obviously at an extremely low frequency. With a suitable device, it is possible to convert the inaudible "breath" of the cave into a sound, a kind of speech of the cave itself. This area of research may lead to the revelation of further information on cave system characteristics.

Throughout his entire life, Badino's capacity to work was abnormally great, which resulted in a very large number of documents about the most diverse caving subjects, and this work was reported in some 500 papers, several of them being true milestones in karst science. In order to understand why Giovanni became such an exceptional scientist and cave explorer, it is worth considering a statement of the English explorer Apsley Cherry-Garrard (1886-1959): "Exploration is the physical expression of the intellectual passion". This affirmation can help explain why an intellectually 

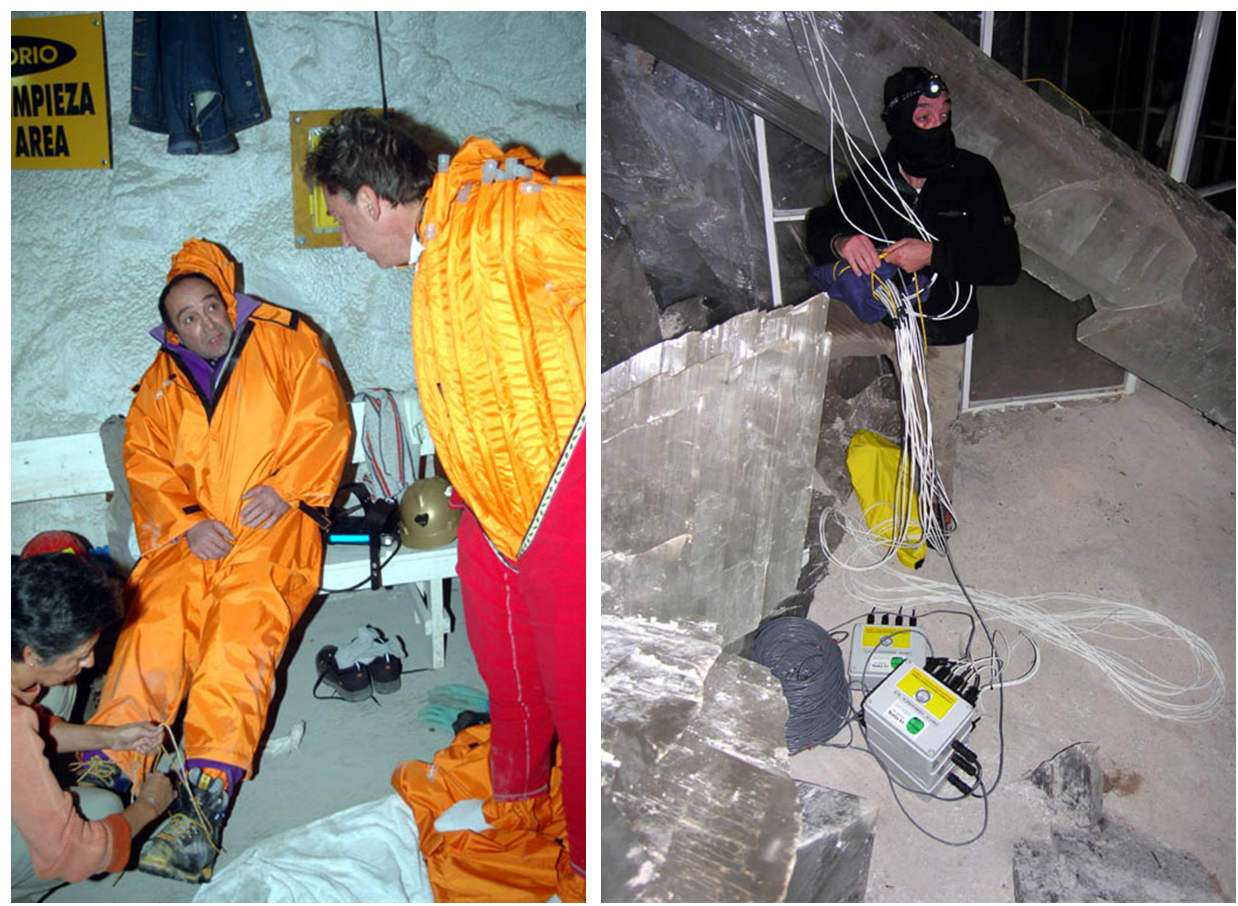

G. Badino preparing to enter in the Cueva de los Cristales (Naica, Mexico) during the 2007 expedition (left) to instal a temperature acquisition device (right)

passionate physicist is also an explorer. And caves are the best environment to explore!

After a long illness, Giovanni Badino passed away on August $8^{\text {th }}$ in his home in the mountains above Savona, still at work in his very last days. He had presented a couple of papers at the $3^{\text {rd }}$ International Symposium of Speleology (Varenna, Italy), his last scientific meeting, just four months before his death, but, even later, the International Journal of Speleology

\section{Badino's speleological milestones}

Badino G., 1990 - Fisica dei buchi nell'acqua Proceedings $1^{\text {st }}$ International Symposium of Glacier caves and karst in Polar Regions, Madrid: 119-133.

Badino G., 1992 - Tecniche di grotta: per fare dei passi avanti dall'orlo dell'abisso. Società Speleologica Italiana, Bologna, 207 p.

Badino G., 1995 - Phenomenology and first numerical simulations of the phreatic drainage network inside glaciers. $3^{\text {rd }}$ International Symposium "Cavitès Glaciares et Cryokarst en Region Polaires et de Haute Montaigne". Chamonix, France (1994): 47-54.

Badino G., 1995 - Fisica del clima sotterraneo. Memorie dell'Istituto Italiano di Speleologia II (7) $136 \mathrm{p}$.

Badino G., 2000 - It is always dark in caves? International Journal of Speleology, 29B (1-4): 89-126.

Meneghel M., Badino G., 2002 - Ice caves of Terra Nova Bay (Victoria Land Antarctica) Nimbus, 23-24 (1-4): 130-136.

Badino G., 2003 - Antarctica. In: Gunn, J. (Ed.), Encyclopedia of caves and karst. Fitzroy Dearborn, New York, p. 68-69.

Badino G., 2004 - Clouds in caves. Speleogenesis and Evolution of Karst Aquifers, 2 (2): 1-8.

Badino G., De Vivo A., Piccini L., 2004 - Caves of sky: a journey in the heart of glaciers. La Venta, $153 \mathrm{p}$. received a review and his own revised paper he had written just a few couple of days before passing away.

At the funeral, a large number of friends from all over Italy joined to remember him and his legacy, not only as a renowned colleague and excellent teacher, but also a good friend.

Many thanks for what you have given us, dear Giovanni ...

Badino G., 2005 - Underground drainage systems and geothermal flux. Acta Carsologica, 34 (2): 277-316.

Badino G., 2008 - Crystal giants in the caves of Naica. La Venta, Tintoretto, Treviso, $47 \mathrm{p}$.

Badino G., 2009 - The legend of carbon dioxide heaviness. Journal of Cave and Karst Studies, 71 (1): 100-107.

Badino G., Chignola R., 2009 - The sound of natural caves. Proceedings of the $15^{\text {th }}$ International Congress of Speleology, Kerrville, Texas, 3: 1403-1406.

Badino G., 2013 - Wind, clouds, rains in the dark: the quest for imperceivable meteorological events in the Region of the Dark. Speleologia, 68: 58-60.

Badino G., 2015 - Il subterranean sucking evaporimeter: un nuovo strumento per le misure di umidità in grotta. Memorie dell'Istituto Italiano di Speleologia, 29: 473-477.

Badino G., 2017 - Driving pressure of subterranean airflows: an analysis. Proceedings of the $17^{\text {th }}$ International Congress of Speleology, Sydney, 2: 205-208.

Badino G., 2017 - A theoretical approach to the estimation of local entropy production in caves. Proceedings of the $17^{\text {th }}$ International Congress of Speleology, Sydney, 2: 209-213.

Badino G., 2018 - Geothermal flux and phreatic speleogenesis in gypsum, halite, and quartzitic rocks. International Journal of Speleology, 47 (1): in press. 